OPEN ACCESS

Edited by:

You-Hee Cho,

CHA University, South Korea

Reviewed by:

Dong-Chan Oh,

Seoul National University,

South Korea

Yoonkyung Park,

Chosun University, South Korea

${ }^{*}$ Correspondence:

Pedro I. Da Silva Jr.

pedro.junior@butantan.gov.br; peisjr@gmail.com

Specialty section:

This article was submitted to

Antimicrobials, Resistance

and Chemotherapy,

a section of the journal

Frontiers in Microbiology

Received: 21 June 2018 Accepted: 03 September 2018

Published: 28 September 2018

Citation:

Díaz-Roa A, Patarroyo MA, Bello FJ and Da Silva PI Jr (2018) Sarconesin:

Sarconesiopsis magellanica Blowfly Larval Excretions and Secretions With Antibacterial Properties.

Front. Microbiol. 9:2249.

doi: 10.3389/fmicb.2018.02249

\section{Sarconesin: Sarconesiopsis magellanica Blowfly Larval Excretions and Secretions With Antibacterial Properties}

\author{
Andrea Díaz-Roa ${ }^{1,2,3}$, Manuel A. Patarroyo ${ }^{4,5}$, Felio J. Bello ${ }^{6,7}$ and Pedro I. Da Silva Jr. ${ }^{1,3 *}$ \\ 1 Laboratório Especial de Toxinologia Aplicada, Instituto Butantan, São Paulo, Brazil, ${ }^{2}$ PhD Programme in Biomedical \\ and Biological Sciences, Universidad del Rosario, Bogotá, Colombia, ${ }^{3}$ Biomedical Sciences Institute, Universidade de \\ São Paulo, São Paulo, Brazil, ${ }^{4}$ Molecular Biology and Immunology Department, Fundación Instituto de Inmunología \\ de Colombia, Bogotá, Colombia, ${ }^{5}$ Basic Sciences Department, School of Medicine and Health Sciences, Universidad del \\ Rosario, Bogotá, Colombia, ${ }^{6}$ Faculty of Agricultural and Livestock Sciences, Program of Veterinary Medicine, Universidad \\ de La Salle, Bogotá, Colombia, ${ }^{7}$ Medicine Faculty, Universidad Antonio Nariño, Bogotá, Colombia
}

Larval therapy (LT) is an alternative treatment for healing chronic wounds; its action is based on debridement, the removal of bacteria, and stimulating granulation tissue. The most important mechanism when using LT for combating infection depends on larval excretions and secretions (ES). Larvae are protected against infection by a spectrum of antimicrobial peptides (AMPs); special interest in AMPs has also risen regarding understanding their role in wound healing since they degrade necrotic tissue and kill different bacteria during LT. Sarconesiopsis magellanica (Diptera: Calliphoridae) is a promising medically-important necrophagous fly. This article reports a small AMP being isolated from S. magellanica ES products for the first time; these products were obtained from third-instar larvae taken from a previously-established colony. ES were fractionated by RP-HPLC using C18 columns for the first analysis; the products were then lyophilised and their antimicrobial activity was characterized by incubation with different bacterial strains. These fractions' primary sequences were determined by mass spectrometry and de novo sequencing; five AMPs were obtained, the Sarconesin fraction was characterized and antibacterial activity was tested in different concentrations with minimum inhibitory concentrations starting at $1.2 \mu \mathrm{M}$. Potent inhibitory activity was shown against Gram-negative (Escherichia coli D31, E. coli DH5 $\alpha$, Salmonella enterica ATCC 13314, Pseudomonas aeruginosa 27853) and Gram-positive (Staphylococcus aureus ATCC 29213, S. epidermidis ATCC 12228, Micrococcus luteus A270) bacteria. Sarconesin has a significant similarity with Rho-family GTPases which are important in organelle development, cytoskeletal dynamics, cell movement, and wound repair. The data reported here indicated that Sarconesin could be an alternative candidate for use in therapeutics against Gram-negative and Gram-positive bacterial infections. Our study describes one peptide responsible for antibacterial activity when LT is being used. The results shown here support carrying out further experiments aimed at validating S. magellanica AMPs as novel resources for combating antibacterial resistance.

Keywords: antimicrobial peptide, Sarconesiopsis magellanica, sarconesin, larval therapy, insect peptide 


\section{INTRODUCTION}

Larval therapy (LT) involves applying sterile larvae (usually Diptera from the Calliphoridae family) to an infected nonhealing wound (Raposio et al., 2017); its action is based on four mechanisms: removing necrotic tissue (debridement), disinfecting microorganisms, including methicillin-resistant Staphylococcus aureus (MRSA) (Robinson, 1935; Mumcuoglu, 2001; Bexfield et al., 2004; Nigam et al., 2010), inhibiting and eradicating biofilms (van der Plas et al., 2008; Cazander et al., 2009; Gottrup and Jorgensen, 2011) and stimulating granulation tissue for enhancing healing (Church, 1996; Thomas A.M. et al., 1999; Sherman et al., 2000; Mumcuoglu, 2001; Wolff and Hansson, 2005; Spilsbury et al., 2008).

It has been proposed that larvae release antimicrobial ingredients into wounds in response to infection; some of these ingredients are low molecular weight bacteriostatic compounds, such as p-hydroxybenzoic acid, p-hydroxyphenylacetic acid, dioxopiperazine proline (Huberman et al., 2007) and an enigmatic compound $\left(\mathrm{C}_{10} \mathrm{H}_{16} \mathrm{~N}_{6} \mathrm{O}_{9}\right)$ known as seraticin (Nigam et al., 2010). Other compounds are antimicrobial peptides (AMPs) originating from the immune system that, when applied into wounds, contribute to their healing (Thomas A.M. et al., 1999; Bexfield et al., 2004). Such insect peptides belong to the diptericin, cecropin, and defensin groups (Hoffmann and Hetru, 1992; Bulet and Stocklin, 2005). Lucifensin is one of the well characterized AMPs; it is derived from Lucilia sericata larvae and has been found as a constituent of larval excretions and secretions (ES) (Cerovsky et al., 2010). This molecule was originally isolated from Lucilia sericata larval intestine, later being detected in the salivary glands, fat body and haemolymph. However, it has been shown that it is the larval immune system which induces the production of these substances in the fat body when activated in response to an infectious environment (Valachova et al., 2013) for its rapid release into the haemolymph.

Insects respond to bacterial attacks by rapidly producing AMPs which have a broad spectrum of activity against Grampositive and Gram-negative bacteria, and against fungi; more recently, it has been demonstrated that AMPs have activity against some parasites and viruses (Yi et al., 2014). Insectisolated AMPs can be classified on the basis of their sequence and structural characteristics into three categories: linear peptides which can form an alpha-helical structure and contain no cysteine residues, such as cecropins; cyclic peptides containing disulphide bridges, such as defensins; and linear peptides having remarkable contents of one or two amino acid (aa) residues, mostly proline and/or glycine (e.g., pyrocoricins and diptericins) (Bulet et al., 1999).

These peptides are conserved host immune system evolutionary components forming part of the first line of defense against infections and have been identified in almost all life forms. Insect isolates make up the most abundant group of more than 2,798 AMPs listed in the antimicrobial peptide database ${ }^{1}$. AMPs are synthesized in the fat body (the equivalent of the liver in mammals), epithelial cells and certain

\footnotetext{
${ }^{1}$ http://aps.unmc.edu/AP/main.php
}

haemolymph cells (the equivalent of mammalian blood), and spread throughout the body by this medium for counteracting infection. Most of these peptides are cationic AMPs having a molecular mass of less than $5 \mathrm{kDa}$ (Brown and Hancock, 2006). In contrast to conventional antibiotics, AMPs do not induce microbial resistance and require only a short time to induce microorganism death (Yeaman and Yount, 2003).

Microorganisms' resistance to antibiotics represents an everincreasing difficulty; such situation becomes even more relevant in relation to chronic wounds which are difficult to heal in patients suffering underlying disease (such as diabetes and cardiovascular failure). Polymicrobial colonization by different bacterial strains often occurs in this type of lesion, forming a biofilm, thereby making them more difficult to treat, control and/or eradicate. Recent studies (O'Meara et al., 2014) have demonstrated that conventional antibiotics do not promote chronic wound healing, in addition to generating resistance in bacteria, which is why their general use has been questioned for treating the bacteria colonizing this type of wound. There is thus a need to introduce new or re-emerging strategies which may be effective against microorganisms in chronic, necrotic and infected wounds which do not respond to antibiotic therapy.

Identifying and characterizing antibacterial compounds involved in larval ES during LT is the starting point for the search and typing of natural molecules in insects, mainly dipterans from the Calliphoridae family (Yeaman and Yount, 2003). AMPs have been isolated from purified larvae in just L. sericata (Cerovsky et al., 2010), L. cuprina (El Shazely et al., 2013), and Calliphora vicina (Chernysh et al., 2015) whilst lucifensins have been isolated from larvae, purified, characterized and evaluated. They have been shown to be mainly effective against Gram-positive bacteria, such as MRSA and its strains (Andersen et al., 2010;Cerovsky and Bem, 2014). Amongst the most recent studies on antimicrobial peptides isolated from flies from the Calliphoridae family different to those obtained from larval ES, it is worth mentioning a study by Yakovlev et al. (2017) (Yakovlev et al., 2017), who studied the presence of AMPs in the culture medium from both fat bodies and haemocytes derived of Calliphora vicina larvae. They demonstrated that both cell types synthesized and released an AMPs complex to the culture medium, corresponding to defensins, cecropins, diptericins, and proline-rich peptides. In another study, AMPs extracted from C. vicina larval haemolymph were applied in environments extremely contaminated by germs forming biofilms (under in situ and in vitro conditions), exhibiting strong destructive activity of the matrix and of bacteria adhered to it, these bacteria were resistant to conventional antibiotics, such as Escherichia coli, Staphylococcus aureus, and Acinetobacter baumannii (Gordya et al., 2017). Likewise, this AMP complex containing a combination of defensins, cecropins, diptericins and proline-rich peptides, and interacting synergistically with antibiotics of various classes, produced a much stronger action on the bacterial strains (Staphylococcus aureus, Escherichia coli, Pseudomonas aeruginosa, Klebsiella pneumoniae, and Acinetobacter baumannii) and the biofilm materials, when compared with the antibacterial effect on the same strains in a model of planktonic cultures (Chernysh et al., 2018). 
The S. magellanica species has been reported in Argentina (Mariluis and Mulieri, 2003), Bolivia, Chile, Ecuador and Perú (Pape et al., 2004); Mariluis and Peris have described it as being present in areas over 900 masl (Mariluis and Peris, 1984). In Colombia, it is found in Boyacá and Cundinamarca departments (Hardy, 1966). S. magellanica was reported as the first species colonizing decomposing pigs in Bogotá (an animal bio-model similar to that of humans) (Goff, 2001). Its antibacterial activity has been confirmed, giving better results than those for L. sericata (Diaz-Roa et al., 2014) and it has already been evaluated regarding LT, leading to good effects concerning diabetic wound cicatrisation (Cruz-Saavedra et al., 2016) and in Leishmania lesions (Cruz-Saavedra et al., 2016).

This study was thus aimed at characterizing a novel AMP purified from $S$. magellanica ES. The antimicrobial activity of the peptide so obtained against various Gram-positive and Gramnegative bacteria was also evaluated.

\section{MATERIALS AND METHODS}

\section{Adult S. magellanica Capture and Colony Maintenance}

Insect capture and colony maintenance followed a previously described procedure (Diaz-Roa et al., 2014). Adult S. magellanica forms were captured in the mountainous part of Bogotás Parque Nacional; the park is located 2,600 masl $\left(4^{\circ} 37^{\prime} 8.90 \mathrm{~N}\right.$; $74^{\circ} 3^{\prime} 27.73 \mathrm{~W}$ ). Entomological nets were used for collecting insects which were then stored alive in glass flasks for being transported to the Universidad del Rosario's Medical and Forensic Entomology laboratory. The specimens were kept in $45 \times 45 \times 45 \mathrm{~cm}$ Gerber cages at $20-25^{\circ} \mathrm{C}$, with $60-70 \%$ relative humidity and a $12 / 12 \mathrm{~h}$ photoperiod. The adult forms were fed on a sugar solution (carbohydrate source) and pigs' liver as protein feed necessary for providing continuity for the biological cycle (Rueda et al., 2010); after adults had laid eggs on the liver they were placed in a glass flask with a liver slice until maggots hatched. The maggots were kept in this flask throughout the 3 instars until they reached the pre-pupa stage; they were then put in a flask containing sand until the adults emerged to be released in the same cages to continue the cycle. Third instar maggots were used for extracting their ES.

\section{Extracting S. magellanica ES}

S. magellanica-derived ES were collected from third instar larvae, following a previously described procedure (van der Plas et al., 2008); about 200 larvae were used in each assay. Third-instar larvae were incubated with a bacterial suspension (OD595 $=0.5)$ of each selected strain to activate the immune system and enhance the expression of products having antibacterial activity (Kawabata et al., 2010; Jiang et al., 2012). They were then placed in a $15 \mathrm{~mL}$ Falcon tube and disinfected by adding $0.5 \%$ formaldehyde for $5 \mathrm{~min}$ followed by replacing this solution with $0.5 \%$ hypochlorite with constant shaking for the same amount of time and washed with sterile PBS; $2 \mathrm{~mL}$ sterile PBS was then added to the larvae which were incubated at $25^{\circ} \mathrm{C}$ for $1 \mathrm{~h}$. The larval ES mixture was removed by using a syringe and placed in another tube to continue centrifuging at $13,000 \mathrm{~g}$ at $4^{\circ} \mathrm{C}$ for $10 \mathrm{~min}$. The precipitate was discarded and the supernatant with the ES was sterilized by filtering through a $0.22 \mu \mathrm{m}$ membrane and stored at $-70^{\circ} \mathrm{C}$.

\section{Peptide Purification}

ES were partially purified by Sep-Pak C18 disposable columns for the first analysis; bound material was eluted with $80 \%$ acetonitrile $(\mathrm{ACN})$ in acidified water and freeze-dried. S. magellanica hydrophobic ES (80\%) were then lyophilised and reconstituted in $2 \mathrm{~mL}$ trifluoracetic acid $(0.05 \%$ TFA). ES were purified by semi-preparative reverse-phase high-performance liquid chromatography (RP-HPLC) using a C18 Jupiter column $(10 \mu \mathrm{m} ; 300 \mathrm{~A} ; 10 \mathrm{~mm} \times 250 \mathrm{~mm})$ at $2 \mathrm{~mL} / \mathrm{min}$ flow rate, as previously described (Hou et al., 2011). Fractions were collected manually, absorbance being monitored at $225 \mathrm{~nm}$. Each fraction's antibacterial activity was then determined. RP-HPLC $(1 \mathrm{~mL} / \mathrm{min}$ flow rate) was then used with fractions having antibacterial activity, using an analytical C18 Jupiter column $(10 \mu \mathrm{m} ; 300 \mathrm{~A}$; $4,6 \mathrm{~mm} \times 250 \mathrm{~mm})$. The Sarconesin gradient was open, ACN concentration ranging from $44 \%$ to $54 \%$. Absorbance was monitored at $225 \mathrm{~nm}$, fractions were collected manually and antibacterial activity was tested.

\section{Antimicrobial Assays}

A liquid growth inhibition assay was used for evaluating the fractions' antibacterial activity (Bulet, 2008; Wiegand et al., 2008). Lyophilised fractions were suspended in $500 \mu \mathrm{L}$ Mili Q water; the assay was carried out using 96-well sterile plates. $20 \mu \mathrm{L}$ of the fractions were aliquoted into each well with $80 \mu \mathrm{L}$ of the bacterial dilution, to $100 \mu \mathrm{L}$ final volume. Bacteria were cultured in poor nutrient broth (PB) $(1.0 \mathrm{~g}$ peptone in $100 \mathrm{~mL}$ of water containing $86 \mathrm{mM} \mathrm{NaCl}$ at $\mathrm{pH} 7.4 ; 217 \mathrm{mOsm}$ ). Exponential growth phase cultures were diluted to $5 \times 10^{4}$ $\mathrm{CFU} / \mathrm{mL}(\mathrm{DO}=0.001)$ final concentration (Hetru and Bulet, 1997; Bulet, 2008; Poppel et al., 2015). Sterile water and PB were used as growth control, and streptomycin was used as growth inhibition control. Microtitre plates were incubated for $18 \mathrm{~h}$ at $30^{\circ} \mathrm{C}$; growth inhibition was determined by measuring absorbance at $595 \mathrm{~nm}$. The assay for determining the minimum concentration of peptide required to achieve $100 \%$ growth inhibition was performed using a serial dilution in 96-well sterile plates at $100 \mu \mathrm{L}$ final volume (Silva et al., 2000;Lorenzini et al., 2003;Riciluca et al., 2012); $20 \mu \mathrm{L}$ stock solution was used in each microtitre plate well at twofold serial dilution and added to $80 \mu \mathrm{L}$ of the bacterial dilution. The strains used were Staphylococcus aureus ATCC 29213, S. epidermidis ATCC 12228, Escherichia coli D31, E. coli DH5a, Pseudomonas aeruginosa 27853, Salmonella enterica ATCC 13314, and Micrococcus luteus A270. Microbial growth was measured by monitoring optical density at $595 \mathrm{~nm}$ and assays were performed in triplicate (PerkinElmer Victor 3TM 1420 multilabel counter). The bacterial growth curve of S. aureus with Sarconesin MIC and $1 / 2$ MIC was measured every 15 min for $1 \mathrm{~h}$ and then every hour for $12 \mathrm{~h}$. Graph was backgroundcorrected by subtracting the OD595 of medium without bacteria (Velema et al., 2013; Magi et al., 2015). 


\section{Cytotoxicity (CC)}

The toxicity of Sarconesin peptide against VERO cells (African green monkey kidney fibroblast) was evaluated. Cells were obtained from the American Type Culture Collection (ATCC CCL81; Manassas, VA, United States) and maintained in DMEM culture medium, supplemented with $10 \%$ heatinactivated calf serum. CC was determined using the MTT colorimetric assay. Briefly, the cells were seeded in 96-well plates $\left(2 \times 10^{5}\right.$ cells/well $)$ and cultured for $24 \mathrm{~h}$ at $37^{\circ} \mathrm{C}$ in a humidified atmosphere containing $5 \% \mathrm{CO}_{2}$. Eight two-fold serial dilutions of peptide were performed with DMEM to give solutions with final concentrations ranging from 4, 7 to $600 \mu \mathrm{M}$. Varying concentrations were added and allowed to react with the cells for $48 \mathrm{~h}$, followed by the addition of $20 \mu \mathrm{L}$ MTT ( $5 \mathrm{mg} / \mathrm{mL}$ in PBS) for another $4 \mathrm{~h}$ at $37^{\circ} \mathrm{C}$. Formazan crystals were dissolved by adding $150 \mu \mathrm{L}$ isopropanol and incubating at room temperature until all crystals were dissolved. Absorbance at $550 \mathrm{~nm}$ was measured using a microplate ELISA reader. Cell survival was calculated using the following formula: survival $(\%)=($ A550 of peptide-treated cells/A550 of peptide-untreated cells)* 100 (Sayegh et al., 2016).

\section{Haemolytic Activity}

Fresh human red blood cells (hRBCs) were washed 3 times with PBS $(35 \mathrm{mM}$ phosphate buffer, $0.15 \mathrm{M} \mathrm{NaCl}$, $\mathrm{pH}$ 7.4) by centrifugation for $7 \mathrm{~min}$ at $1000 \times \mathrm{g}$, and resuspended in PBS to a final $4 \%(\mathrm{v} / \mathrm{v})$ concentration. Sarconesin solutions (serial 2-fold dilutions in PBS) were added to $100 \mathrm{uL}$ hRBC suspension to a final $200 \mu \mathrm{L}$ volume, and incubated for $1 \mathrm{~h}$ at $37^{\circ} \mathrm{C}$. Hemoglobin release was monitored by measuring the supernatant absorbance at $405 \mathrm{~nm}$ with a Microplate ELISA Reader. The haemolysis percentage was expressed in relation to a $100 \%$ lysis control (erythrocytes incubated with $0.1 \%$ Triton X-100); PBS was used as a negative control (Nan et al., 2012; Chaparro and da Silva, 2016).

\section{Mass Spectrometry}

Active antibacterial fractions were analyzed by mass spectrometry LC-MS/MS on a LTQ-Orbitrap Velos (Thermo Scientific) coupled to an Easy-nLCII liquid nano-chromatography system (Thermo Scientific). The chromatographic step involved using $5 \mu \mathrm{L}$ of each sample automatically on a C18 pre-column $(100 \mu \mathrm{m}$ I.D. $\times 50 \mathrm{~mm}$; Jupiter $10 \mu \mathrm{m}$, Phenomenex Inc., Torrance, California, United States) coupled to a C18 analytical column (75 $\mu \mathrm{m}$ I.D. $\times 100 \mathrm{~mm}$; ACQUA $5 \mu \mathrm{m}$, Phenomenex Inc.). The eluate was electro-sprayed at $2 \mathrm{kV}$ and $200^{\circ} \mathrm{C}$ in positive ion mode. Mass spectra were acquired by FTMS analyser; full scan (MS1) involved using $200-2,000 \mathrm{~m} / \mathrm{z}(60,000$ resolution at $400 \mathrm{~m} / \mathrm{z}$ ) as mass scan interval with the instrument operated in data dependent acquisition mode, the five most intense ions per scan being selected for fragmentation by collision induced dissociation. The minimum threshold for selecting an ion for a fragmentation event (MS2) was set to 5,000 cps.
The dynamic exclusion time used was $15 \mathrm{~s}$, repeating at $30 \mathrm{~s}$ intervals.

\section{Bioinformatics}

The MS/MS peak list files were submitted to an in-house version of the MASCOT server (Matrix Science, United States) and screened against the Uniprot database. PEAKS 8.5 (Bioinformatics Solutions Inc., Waterloo, Ontario, Canada) de novo sequencing/database search software was used for establishing sequences. Analysis involved $10 \mathrm{ppm}$ error tolerance for precursor ions and 0.6 $\mathrm{Da}$ for fragment ions. Oxidation was considered a variable modification.

The Sarconesin sequence was analyzed for similarities with the $L$. sericata and L. cuprina genome and transcriptome and also with other proteins registered in the National Center for Biotechnology (NCBI) public database, using the Basic Local Alignment Search Tool (BLASTp), with default parameters $^{2}$ (Altschul et al., 1997). The sequences' physicalchemical parameters were calculated using the PepCalc tool ${ }^{3}$. Gene Runner was used for nucleotide translation to protein and Seaview (Gouy et al., 2010) and Boxshade ${ }^{4}$ was used for making and formatting alignments' shaded background. The Chimera structure prediction tool (accessed through the European Bioinformatics Institute ${ }^{5}$ was used for obtaining the three-dimensional (3D) images of secondary structure.

\section{Circular Dichroism (CD)}

The far-UV (190-250nm) CD spectrum of the peptide was recorded in a Jasco J810 spectropolarimeter (Jasco Inc., Japan) at $25^{\circ} \mathrm{C}$ and in a $0.1 \mathrm{~cm}$ path length quartz cell. All CD spectra were recorded after accumulation of 4 runs and smoothed using a FFT (Fast Fourier Transform) filter to minimize background effects. The solvents used in the experiment were pure water and 10,30 and $50 \% \mathrm{v} / \mathrm{v}$ solutions of 2,2,2 trifluoroethanol (TFE) in water.

\section{Mechanism of Action \\ Membrane Integrity and Esterase Activity}

Mid-log phase E. coli cells $\left(2 \times 10^{8} \mathrm{CFU} / \mathrm{mL}\right)$ were incubated with or without MIC peptide solution at $37^{\circ} \mathrm{C}$. The bacterial membrane integrity was measured by fluorometry and microscopy using propidium iodide (PI) to $60 \mu \mathrm{M}$ final concentration in the dark for $15 \mathrm{~min}$, followed by measuring fluorescence with excitation/emission wavelengths of $485 / 620 \mathrm{~nm}$ (Faisal et al., 2016). For Esterase activity, $180 \mu \mathrm{L}$ were transferred to a 96-well black plate which was added $20 \mu \mathrm{L}$ of $250 \mu \mathrm{M}$ 5(6)-Carboxyfluorescein diacetate (CFDA), incubated in dark for $30 \mathrm{~min}$, followed by measurement of fluorescence with excitation/emission wavelengths of 485/535 nm (Nocker et al., 2011; Yang et al., 2017). PI microscope slides, were made by depositing drops of melted agarose $1 \%(w / v)$; after placing $20 \mu \mathrm{L}$ of the cells onto solidified agar pad for immobilisation, the

\footnotetext{
${ }^{2}$ http://blast.ncbi.nlm.nih.gov/ [accessed April 23, 2018]

${ }^{3}$ http://pepcalc.com/ [accessed April 30, 2018]

${ }^{4}$ http://www.ch.embnet.org/software/BOX_form.html

${ }^{5}$ http://www.ebi.ac.uk/thornton-srv/databases/profunc/ [accessed April 30, 2018]
} 
dried culture was covered with a glass coverslip and observed under a microscope (Carretero et al., 2018). Microscopy was performed using a Leica TCS SP8 confocal laser scanning microscope, the images were processed with Leica software LAS X.

\section{DNA Staining}

Treated and untreated bacterial cells were fixed on a slide, permeabilised with ethanol, and stained with 4,6-diamidino2-phenylindole (DAPI) to visualize the DNA using a confocal microscope.

\section{Gel Retardation Assay}

The binding of Sarconesin to E. coli DH5 $\alpha$ genomic DNA was evaluated by a gel retardation assay (Teng et al., 2014). E. coli genomic DNA was extracted following the method of Landry et al. (1993). Seven two-fold increasing amounts of Sarconesin peptide (3.1 to $200 \mu \mathrm{M}$ ) were incubated for 1 hour with $500 \mathrm{ng}$ of genomic DNA. The mixture was incubated for 1 hour at room temperature and analyzed by electrophoresis on a $0.8 \%$ agarose gel (Yang et al., 2017).

\section{Statistical Analysis}

All statistical analyses were performed using GraphPad Prism software (version 7.00). Bacterial growth curve after Sarconesin treatment was compared to the untreated control using a oneway ANOVA $(\alpha=0.05)$. Statistical comparison of combination treatment in toxicity assays was done using a one-way ANOVA $(\alpha=0.05)$ with Dunnett's multiple comparisons test.

\section{RESULTS}

\section{Peptide Purification}

ES material, analyzed by RP-HPLC, was lyophilised, suspended in water and antibacterial activity was tested. Antibacterial activity was quantified by plate growth inhibition assay using a Grampositive M. luteus A270 bacteria as test-organism (Figure 1). Five of these fractions had antibacterial activity. Fractions 2, 3, 4, and 5 had anti- $P$. aeruginosa activity whilst the other compounds having no activity against $P$. aeruginosa were tested against the Gram-positive M. luteus. Activity was found in fraction 1; fractions having antimicrobial activity were eluted at 8.1, 50.9, $51.7,52.1$, and $64.9 \mathrm{~min}$ and chromatographed again in the same system with an analytic C18 column. All antimicrobial fractions were analyzed by mass spectrometry; when compared through a preliminary database search, just fraction 3 showed homogeneity with Diptera proteins. Purification of this fraction revealed the 3.2 molecule, having antibacterial activity against $M$. luteus.

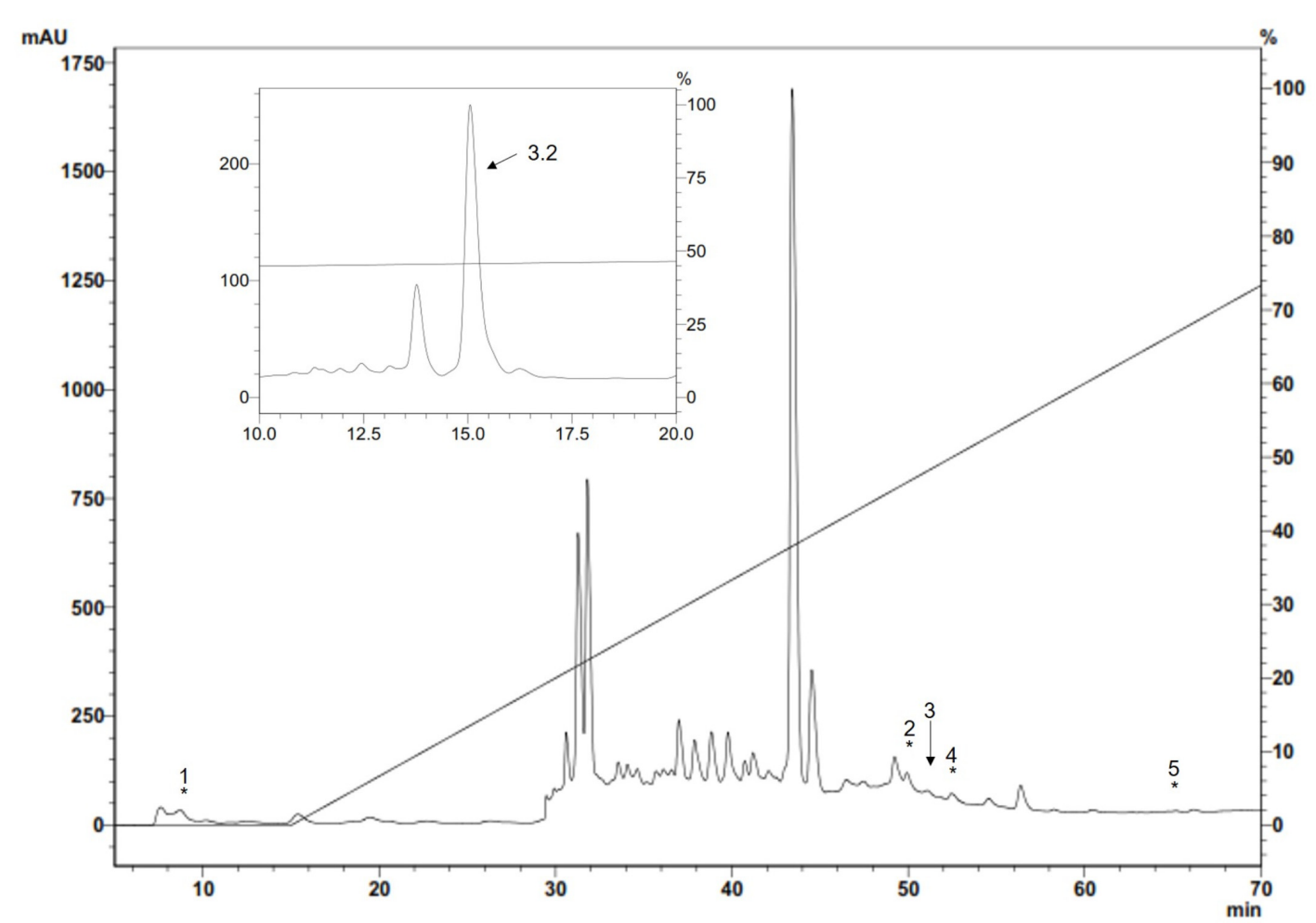

FIGURE 1 | Antimicrobial fractions from S. magellanica ES eluted with $80 \%$ ACN from a Sep-Pak cartridge obtained from the first purification step by RP-HPLC. Chromatography involved using a semi-preparative Jupiter C18 column (10 $\mu \mathrm{m} ; 300 \mathrm{~A} ; 10 \mathrm{~mm} \times 250 \mathrm{~mm})$ with a 0-80\% linear gradient of ACN/0.05\% TFA in $\mathrm{H} 2 \mathrm{O} / 0.05 \%$ TFA for $60 \mathrm{~min}$ at $2 \mathrm{~mL} / \mathrm{min}$ flow rate. Absorbance was monitored at $225 \mathrm{~nm}$. The fractions indicated by an asterisk had antimicrobial activity and were eluted at 8.1, 50.9, 51.7, 52.1, and 64.9 min; fraction 3 labeled with an arrow was chromatographed again in the same system with an analytic Jupiter C18 column (10um; 300A; $4.6 \mathrm{~mm} \times 250 \mathrm{~mm}$ ) and run in $44-54 \%$ solution B for $60 \mathrm{~min}$ (inset). The eluted 3.2 fraction (i.e., Sarconesin) had antibacterial activity and was purified. 
TABLE 1 | MIC, minimum inhibitory concentration; MIC refers to the concentration needed for achieving $100 \%$ inhibition of growth.

\begin{tabular}{llc}
\hline & Strain & Sarconesin MIC \\
\hline Gram + & M. luteus A270 & $4.7 \mu \mathrm{M}$ \\
& S. aureus ATCC 29213 & $1.2 \mu \mathrm{M}$ \\
Gram - & S. epidermidis ATCC 12228 & $1.2 \mu \mathrm{M}$ \\
& P. aeruginosa ATCC 27853 & $4.7 \mu \mathrm{M}$ \\
& E. coli D31 & $2.4 \mu \mathrm{M}$ \\
& E. coli DH5 $\alpha$ & $2.4 \mu \mathrm{M}$ \\
& S. enterica ATCC 13314 & $2.4 \mu \mathrm{M}$ \\
\hline
\end{tabular}

\section{Antimicrobial Assays}

The peptides were studied regarding their potential for inhibiting Gram-positive and Gram-negative bacterial growth. Sarconesin MIC was the same $(4.7 \mu \mathrm{M})$ for M. luteus A270 and P. aeruginosa ATCC 27853; minimum MIC $(1.2 \mu \mathrm{M})$ was obtained for S. aureus ATCC 29213 and S. epidermidis ATCC 12228, and E. coli D31 and DH5 $\alpha$ MIC was $2.4 \mu \mathrm{M}$ (Table 1). Sarconesin MIC exhibited its effect in the exponential phase of $S$. aureus growth curve, which was reached after more than $180 \mathrm{~min}$, incubation with 1/2 MIC showed a decrease of the bacterial growth (Figure 2A).

\section{Toxicity}

The CC activity of Sarconesin was tested against the Vero cell line (Figure 2B). No sign of CC was observed with Sarconesin, even at the highest tested concentration, i.e., $600 \mu \mathrm{M}$. The viability of the cells was approximately $92 \%$ after exposure to Sarconesin. Selectivity index was not calculated as no CC50 values were found in the maximum evaluated concentrations. A very low $(<2 \%)$ haemolytic activity was observed upon incubating human red blood cells with Sarconesin at the highest concentration tested $(600 \mu \mathrm{M})$ (Figure 2C).

\section{Mass Spectrometry}

Mass spectrometry analysis of the Sarconesin fraction revealed a molecule having a mass of 1,471.84 Da. The complete Sarconesin aa sequence obtained by PEAKS de novo sequencing revealed a 13 aa sequence having a posttranslational modification (PTM): TPm( + 16)LLVGTKLDLR. Collision-induced dissociation spectrum from mass/charge $(\mathrm{m} / \mathrm{z})$ of its double charged ion gave $[\mathrm{M}+2 \mathrm{H}] 2+, \mathrm{m} / \mathrm{z}$ 736.9266 (Figure 3). Characterizing the peptide's primary structure with the MASCOT tool gave the TPFLLVGTQIDLR sequence.

Knowing the sequence, proteomic, and peptidomic bioinformatics tools were used for predicting Sarconesin's significant physicochemical characteristics. ExPASy's (SIB Bioinformatics Resource Portal) PepDraw and Pep-Calc.com sequence analysis yielded a potential peptide isoelectric point (pI), molar extinction coefficient and net charge (Table 2). The peptide was predicted to have one Asp negatively-charged aa residue and a positively-charged Arg residue, thereby contributing to the peptide's neutral characteristics ( 0 net charge). Four of the 13 aa were predicted to be hydrophobic

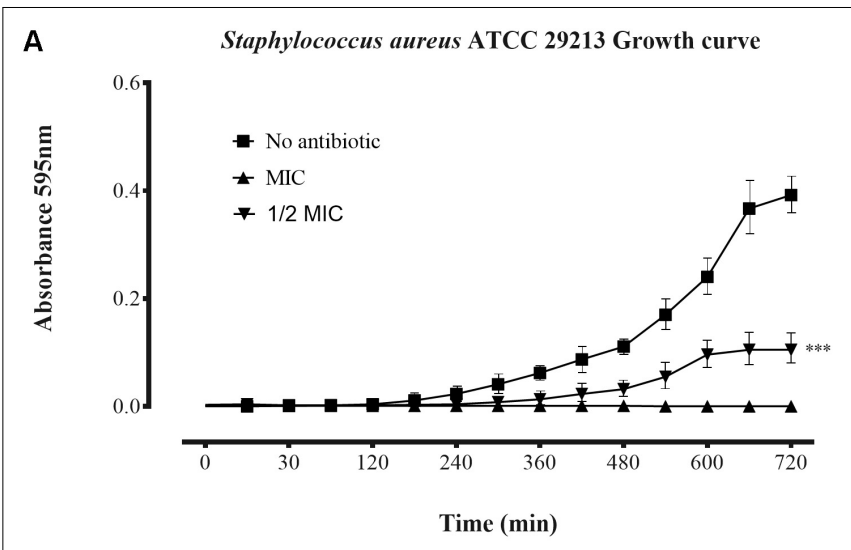

B

Cytotoxicity in Vero Cells

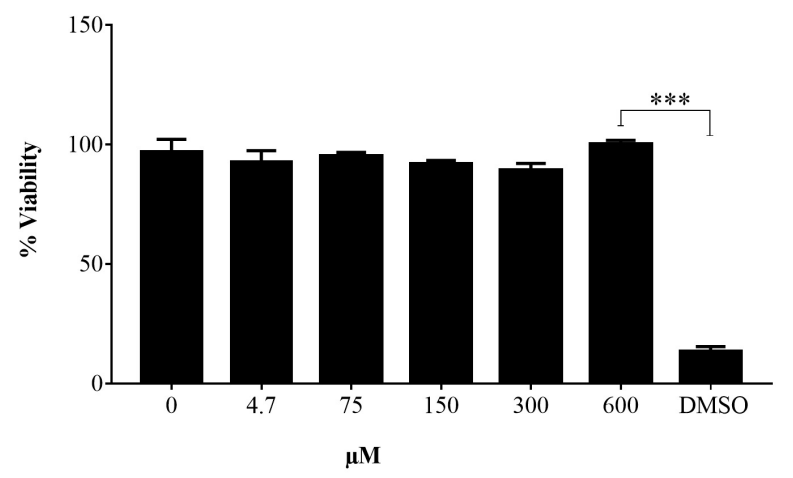

C

Haemolytic Activity

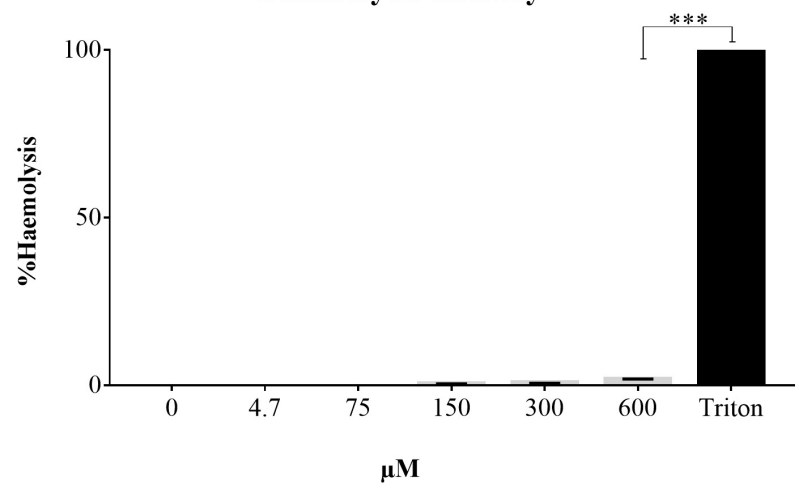

FIGURE 2 | Time growth curve and toxicity assays. (A) Growth curve of S. aureus ATCC 29213 incubated with Sarconesin. Bacterial growth was inhibited and antibacterial effect was detected in the exponential phase. (B) Cytotoxicity and (C) Haemolytic activity of Sarconesin on the VERO cell line and fresh human red blood cells respectively, showing a very low toxicity even at the maximum tested concentration of $600 \mu \mathrm{M}$.

(1 Ile, 3 Leu), suggesting poor water solubility for Sarconesin. ExPASy's ProtParam tool predicted that the peptide would remain intact for up to $7.2 \mathrm{~h}$ in mammalian reticulocytes (in vivo), $>20 \mathrm{~h}$ in yeast and $>10 \mathrm{~h}$ in the Gram-negative bacterium E. coli (in vivo). This was likely due to the presence of a $\operatorname{Thr}(\mathrm{T})$ residue at the $\mathrm{N}$-terminus. 


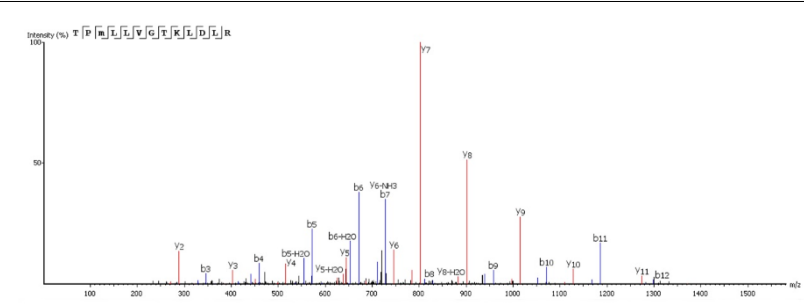

FIGURE 3 | The complete Sarconesin aa sequence was obtained by mass spectrometry (MS/MS) fragmentation; representative de novo sequencing of Sarconesin. CID spectrum from mass/charge $(\mathrm{m} / \mathrm{z})$ of its double charged ion gave $[\mathrm{M}+2 \mathrm{H}] 2+, \mathrm{m} / \mathrm{z}$ 736.9266. The ions from y (red) and $\mathrm{b}$ (blue) series (marked at the top of the spectrum) represent the primary structure: TPm( + 16)LLVGTKLDLR. The sequenced peptide's internal fragments whose ions were found in the spectrum are represented by standard aa letter code.

TABLE 2 | Physicochemical parameters calculated using ExPASy PepDraw and Pep-Calc.com (accessed April 30th 2018).

\begin{tabular}{lcc}
\hline \multicolumn{3}{c}{ Peptide properties } \\
\hline Sequence: & TPFLLVGTQIDLR & Net charge vs. $\mathrm{pH}$ \\
Length: & 13 & 1471.8372 \\
Mass: & 6.42 \\
Isoelectric point (pl): & 0 & \\
Net charge at pH 7: & $8.87 \mathrm{Kcal}^{*} \mathrm{~mol}^{-1}$ & \\
Hydrophobicity: & poor water solubility & \\
Estimated solubility: & $\mathrm{O} \mathrm{M}^{-1 *} \mathrm{~cm}^{-1}$ &
\end{tabular}

\section{Protein Model}

A search for TPFLLVGTQIDLR in databases found matches with cell division control protein 42 (CDC42) sequences from humans, cows and fruit flies, having $100 \%$ sequence similarity. All sequences are referred to by their NCBI accession numbers ${ }^{6}$ to minimize confusion: $\mathrm{CDC} 42$ cell division control protein 42 homologue OS = Bos taurus (Q2KJ93), CDC42_HUMAN Chain A, structure of the Rho Family Gtp-binding protein Cdc42 in complex with the multifunctional regulator Rhogdi (gi| 7245832| 1DOA_A), CDC42_DROME CDC42 homologue $\mathrm{OS}=$ Drosophila melanogaster $\mathrm{GN}=\mathrm{Cdc} 42 \mathrm{PE}=1 \mathrm{SV}=1$ (P40793). The BLASTp 2.6.1 + tool for comparing the sequence obtained with those for other Lucilia species proteins found $69 \%$ identity with a similar sequence previously report as a Rasrelated protein Rac1 [Lucilia cuprina, another blowfly from the Calliphoridae family]: GenBank: KNC23156.1.

Sarconesin sequence was sought in the genomes and transcriptomes reported for L. cuprina (genome ASM118794V1, transcriptome SRX907163) and L. sericata (genome ASM101483V1, transcriptome ERX614478, 3-4 day pupa transcriptome SRX087348). Sarconesin was found in all of them (L. sericata genome scaffold JXPF01028806.1 and transcriptomes ERR658157.22222021.1 and pupa SRR350018.17744834.1. L. cuprina genome scaffold JRES01000256.1 and transcriptome SRR1853100.27006533.2 (accessed May 16th, 2018) (Figure 4A).

${ }^{6}$ https://www.ncbi.nlm.nih.gov/
The exon containing Sarconesin in the JXPF01028806.1 scaffold (GenBank) was located and compared to other proteins by Blastp for determining which organisms had the greatest similarity with the gene. It was shown that this gene was mainly present in other Diptera species (Stomoxys calcitrans XP_013103099.1, Drosophila sechellia XP_002039460.1, Musca domestica XP_005189222.1, Anopheles gambiae CAA93820.1, and Ceratitis capitate XP_004518385.1), having 100\% similarity. It was established that Sarconesin formed part of a CDC42 conserved domain (Figure 4B). The Sarconesin model was built using CDC42's known structure (PDB ID: 1DOA) since it has $100 \%$ identity with bovine CDC42 and a PDB model is available. Figure 4C shows the homology model constructed for Sarconesin.

\section{Circular Dichroism (CD)}

$\mathrm{CD}$ deconvolution software was not suitable for peptide analysis, since it was designed for larger proteins (Bochicchio and Tamburro, 2002), so the peptide's secondary structure analysis was thus made in a qualitative way, by comparing with $\mathrm{CD}$ spectra obtained from known secondary structures of the literature. CD spectra of the peptide were obtained at $25^{\circ} \mathrm{C}$, in water and in TFE/water ranging from 0 to $50 \%$ $\mathrm{v} / \mathrm{v}$ (Figure 5). In water, the CD spectrum showed a strong negative band around $208 \mathrm{~nm}$ and a moderate positive band around $190 \mathrm{~nm}$. As TFE concentration increased, the negative band became less intense and the positive band became more intense and a shoulder between 220 and $230 \mathrm{~nm}$ appeared. TFE has the property of aggregating itself around peptide molecules promoting the displacement of the solvation layer, thereby favoring the formation of intra-peptide hydrogen bonds, stabilizing the peptide's secondary-structure. $\mathrm{CD}$ spectra features suggested a mixture of $3_{10}$-Helix and $\alpha$-Helix conformations (Berova et al., 2012). In water, the 310 -Helix proportion was favored and as the TFE concentration in solution increased, the $\alpha$-Helix contribution also increased, suggesting that the $\alpha$-Helix conformation could be predominant in low dielectric environment, like in a phospholipidic membrane.

\section{Mechanism of Action Membrane Integrity and Esterase Activity}

The red fluorescent dye propidium iodide (PI), which is kept on the outside of intact membranes, can penetrate damaged cell membranes and intercalate into nucleic acids. The fluorescence intensity of PI indicates the level of cell membrane integrity. In the absence of peptide, cells exhibited no PI staining, indicating that membranes were intact (Figures 6, 7). After treatment with Sarconesin, the percentage of PI-permeable E. coli cells increased. This suggested that the inner membrane of $E$. coli was disrupted after treatment with Sarconesin. Also, an alteration in the esterase activity when compared with bacteria control was observed.

\section{DNA Staining}

Neither untreated bacteria nor Sarconesin-treated bacteria showed DNA fluorescence, indicating that DNA was not denatured with Sarconesin treatment (Figure 7). 


\section{A \\ Sarconesin \\ JXPF01028806.1 ERR658157.2222 SRR1853100.2700 JRES 01000256.1 Rac1_L.cuprina CDC $4 \overline{2}$ Human CDC42-Bovin CDC42_Drome SRR350018.17744 B}

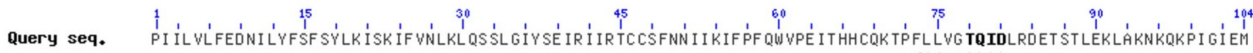
Non-specific
hits hits Superfanilies

C

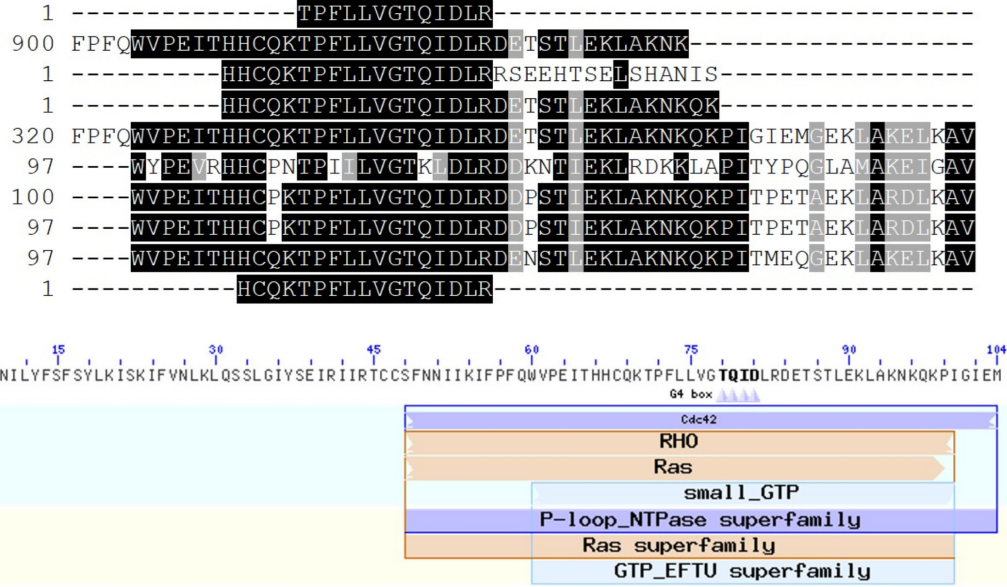

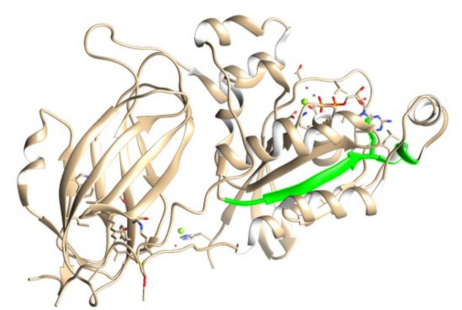

FIGURE 4 | Sarconesin alignment and protein model. (A) Sarconesin multiple sequence alignment against selected proteins. (https://www.ncbi.nlm.nih.gov/): CDC42 cell division control protein 42 homologue OS = Bos taurus (Q2KJ93), CDC42_HUMAN Chain A, structure of the Rho family Gtp-binding protein Cdc42 in complex with the multifunctional regulator Rhogdi (gil 7245832 1 1DOA_A), CDC42_DROME Cdc42 homologue OS = Drosophila melanogaster GN = Cdc42 PE = 1 $\mathrm{SV}=1$ (P40793), Ras-related protein Rac1 [Lucilia cuprina] GenBank: KNC23156.1. Sarconesin has 100\% sequence similarity with CDC proteins and 69\% with Rac from L. cuprina. Translated sequences from L. sericata. Genome scaffold (JXPF01028806.1), transcriptomes ERR658157.22222021.1 and pupa SRR350018.17744834.1 genome scaffold (JRES01000256.1) and L. cuprina transcriptome SRR1853100.27006533.2. (B) Conserved domains found in JXPF01028806.1 L. sericata Blastp, showing Sarconesin a conserved residue from CDC42 domain. (C) Representative model of human CDC42 (PDB ID: 1DOA_A). Sarconesin is encrypted in a site between residues 111 and 123 (green), which folds as a $\beta$-sheet.

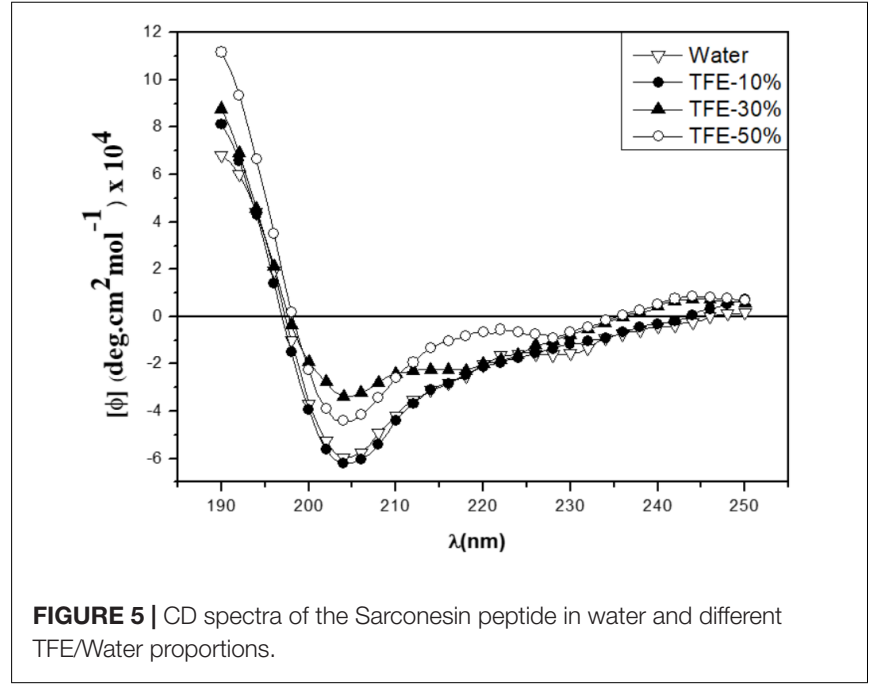

DNA Gel Movement Retardation

In an attempt to clarify the molecular mechanism of action, DNAbinding properties of Sarconesin were examined by analysing electrophoretic migration of DNA. The migration of E. coli genomic DNA suppressed by Sarconesin at 50, 100, and $200 \mu \mathrm{M}$ (Figure 8). This result indicated that Sarconesin can bind to bacterial DNA.

\section{DISCUSSION}

Bacterial resistance against antibiotics has created special interest in searching for new compounds as potential antimicrobial drugs which might be more effective in developing new therapeutic tools (Chernysh et al., 2015). The present work led to finding a new sequence from S. magellanica; its antibacterial activity was screened and its biochemical and structural properties were elucidated by sequence homology. One AMP responsible for the antibacterial activity previously reported in S. magellanica was found (Diaz-Roa et al., 2014). Sarconesin was seen to have 1,471.8372 Da mass and similarity with Cdc42 and Rac proteins; the AMP was embedded in a site between human Cdc42 residues 111 and 123 , folding as a $\beta$-sheet. A search for the peptide in AMPs database did not reveal any similarity with previously reported AMPs; however, this new peptide could be part of the family of linear AMPs (Giuliani et al., 2006). 


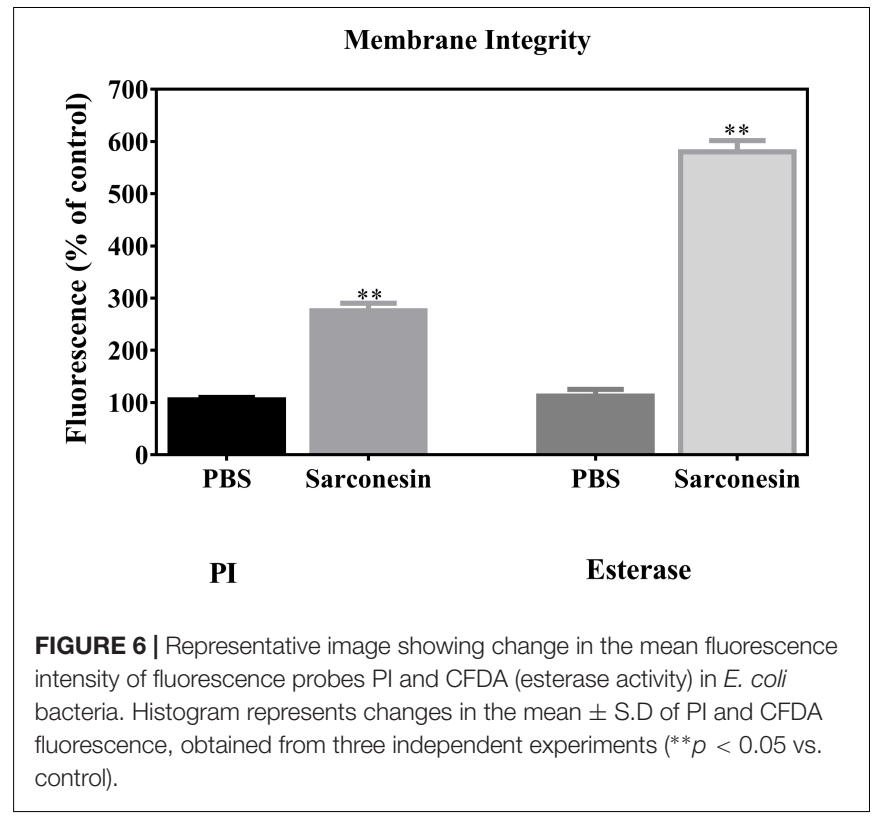

The MIC obtained for Sarconesin in this study suggested a potent activity, similar to that previously reported for other peptides that are active below a $32 \mu \mathrm{g} / \mathrm{mL}$ concentration (Cézard et al., 2011), also, the thanatin peptide has shown a MIC below $2.5 \mathrm{mM}$, which highlights that Sarconesin required less peptide to inhibit bacterial growth (Bulet et al., 1999). This further supports the importance of new effective substances, knowing that several bacteria do become resistant after some days or even hours of exposure (Giacometti et al., 1999). Also, the growth curve of S. aureus showed that Sarconesin has effect in less than $180 \mathrm{~min}$ of incubation. It should be stressed that the fractions having antibacterial activity were absent in the peaks having the greatest absorbance; this has already been observed in other work where defensin, diptericin (Chernysh et al., 2015) and lucifensin have been detected in very tiny peaks (Cerovsky et al., 2010).

Sarconesin has C-terminal $\mathrm{R}$ and $\mathrm{N}$-terminal $\mathrm{T}$ residues, when a search by homology was made, a $\mathrm{K}$ residue was found immediately before the $\mathrm{N}$-terminal $\mathrm{T}$, suggesting that it might be targeted by trypsin-like activity (Chay Pak Ting et al., 2011). The peptide obtained could have resulted from the presence of some proteases and other enzymes in the ES, taking into account that our experimental procedure did not involve trypsin treatment (Nigam et al., 2010); it has already been reported that ES have trypsin and chymotrypsin in their content (Sandeman et al., 1990; Telford et al., 2011). Sarconesin could be a product of processing the $\mathrm{Cdc} 42$ or Rac protein and have other functions in the blowfly related to cell cycle; the derived Sarconesin also has antibacterial activity. It is worth emphasizing that Rac's antimicrobial activity has not been reported before in Calliphoridae blowflies.

As Sarconesin was also present in S. scrofa and the flies' food supplement was liver, it could be possible to assume that the peptide was a subproduct of CDC42 from S. scrofa and not

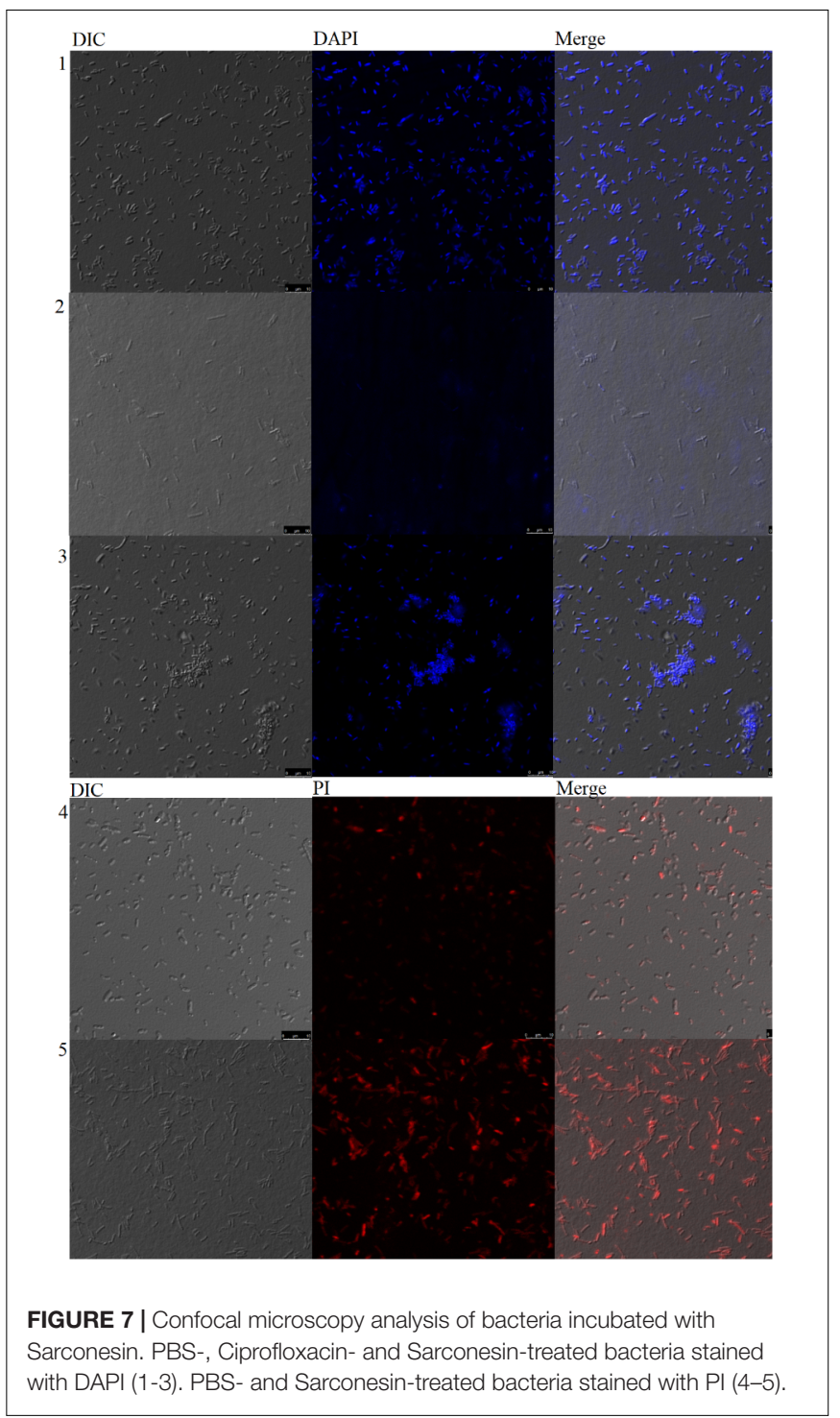

from S. magellanica. However, the presence of Sarconesin in the transcriptome and genome of other Lucilia species showed that this peptide is present in such blowflies, maybe as a subproduct of Diptera. Indeed, multi-omics studies of maggots for larval therapy usually involve using insects fed on bovine liver (Sze et al., 2012; Anstead et al., 2015). The Sarconesin peptide was also present in studies with maggots fed on sheep blood agar as supplement (Poppel et al., 2015; Franta et al., 2016). This exon was also searched in through blast to discard whether it had greater similarity with Diptera species than with S. scrofa. It was found to be more similar with Diptera species having different feeding habits and was also associated with a CDC42 conserved domain. Sarconesin was also found in pupa transcriptome having no contact with liver residue, showing that this peptide's origin could most likely be from the fly.

ES pH is usually 8-8.5 (i.e., in Phaenicia sericata) (Erdmann, 1987; Thomas S. et al., 1999) because of a waste product 


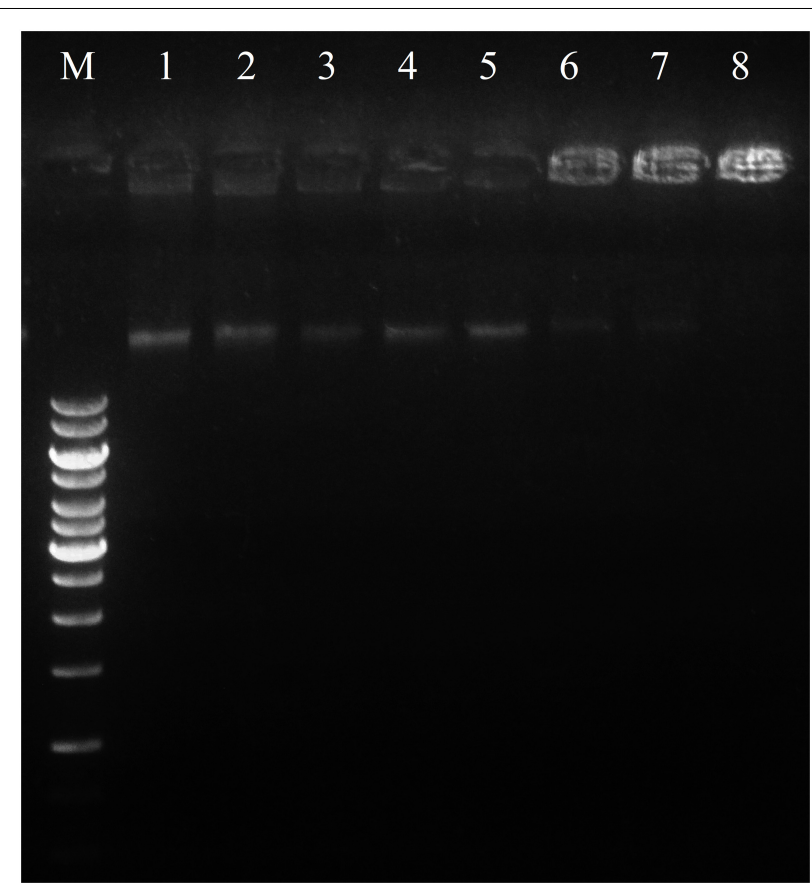

FIGURE 8 | Interaction of Sarconesin with bacterial genomic DNA by a gel migration assay. M, DNA marker GeneRuler $1 \mathrm{~Kb} ; 1-8$, the Sarconesin concentrations were 0, 3.1, 6.25, 12.5, 25, 50, 100, and $200 \mu \mathrm{M}$.

(ammonia), since ammonia increases wound $\mathrm{pH}$, resulting in alkaline conditions which are unfavorable for many bacterial species (van der Plas et al., 2008; Cazander et al., 2009). Sarconesin's net charge would thus be negative as Sarconesin is present in ES and knowing that a protein's net charge is positive at pH below pI (Shaw et al., 2001) (Table 2). This makes Sarconesin an anionic peptide in normal conditions in ES. The mechanism of action regarding bacteria could involve translocation across the membrane (the common mode of action for anionic peptides) (Phoenix et al., 2013), knowing that AMPs can function as direct antimicrobial compounds (Diamond et al., 2009) and also as effector molecules induced upon microbial infection (Zhang et al., 2013).

Sarconesin has $100 \%$ sequence similarity with different organisms' CDC42 protein and 69\% identity with RAC from L. cuprina. Both proteins form part of the Rho-family GTPases (Wennerberg and Der, 2004); Sarconesin may have a similar intracellular mechanism of action, knowing that this protein's expression activates growth factors (Higuchi et al., 2001) and acts as a molecular switch by responding to exogenous and/or endogenous signals, relaying such signals to activate an intracellular biological pathway's downstream components (Johnson, 1999). As the PI assay showed, Sarconesin was confirmed to have a membrane disruption mechanism that has already been reported for other AMPs due to electrostatic interactions, which can be probably followed by hydrophobic patches' insertion into the non-polar interior of the membrane bilayer (Khamis et al., 2015), having a barrelstave model for the channel pore similar to Alamethicin that, as Sarconesin, has a 310 -helix conformation (Nagao et al., 2015). Some morphological changes on bacteria were observed in Sarconesin PI experiment (Figure 7), these most likely occurred when the antimicrobial agent attacked the cell membrane, as has been previously reported by Hyde (Hyde et al., 2006).

Sarconesin induced the release of 6-carboxyfluorescein, indicating an effect resulting from a transient destabilization of the bilayer upon initial interaction, a similar effect previously reported for the magainin-2 peptide (Oren and Shai, 1998). The bacterial DNA, when incubated with Sarconesin and DAPI, did not show degradation and the gel retardation assay showed that Sarconesin strongly bound to DNA in vitro, thus suggesting the possibility of inhibiting intracellular functions via interference with DNA (Shi et al., 2016).

The selectivity index was not established, nevertheless, no CC was found. These findings would point toward the existence of an appreciable selectivity of this compound against bacteria and, therefore, this observation may be an indicator of their safety as drugs for mammalian organisms. To verify whether the peptide was able to disrupt human erythrocyte membranes in an attempt to evaluate the peptide's future pharmacological potential, a haemolytic assay was performed, where the peptide displayed a very low $(<2 \%)$ haemolytic activity in a $600 \mu \mathrm{M}$ final concentration. The haemolytic activity decreased to $0 \%$ in a concentration ranging between 600 and $300 \mu \mathrm{M}$ (Figure 2C). As expected, the peptide has no relevant toxic potential, even when tested a concentration 128 times higher than the M. luteus and $P$. aeruginosa MIC (i.e., $4.7 \mu \mathrm{M}$ ), based on the fact that Sarconesin is identical with a conserved domain from CDC42, molecule present in different human cells that acts as a molecular switch in the control of a variety of eukaryotic processes (Johnson, 1999).

Sarconesin may also have implications for wound healing. It has previously been reported in cell culture that ES from other necrophagous flies increase fibroblast proliferation for wound healing (Polakovicova et al., 2015). Also, specifically Sarconesin has been previously reported as an angiogenesis biomarker of recovery after acute kidney injury, so could be a good candidate for future wound evaluation activities (Titulaer, 2013). The Rho family also has wound-healing properties and the role of GTPases in epithelial remodeling during wound-healing and epithelialmesenchymal transitions has also been previously reported (Van Aelst and Symons, 2002). There is also evidence that Cdc42 plays a major role in wound healing, regarding host defense against infection (Lee et al., 2013). Previously identified natural AMPs from insects are produced by bacteria, fungi, numerous invertebrates, vertebrates, and plants and are usually associated with killing microbes, although they could also be involved in wound repair, inflammation, chemotaxis, and cytokine activity (Ratcliffe et al., 2014).

This article reports, for the first time, a small antimicrobial peptide which is a member of a new Rho family; it contains 13 residues and is active against Gram-positive and Gram-negative bacteria. The native peptide was purified from S. magellanica by RP-HPLC and characterized by amino acid sequencing. Further studies aimed at evaluating its activity against other bacteria, 
fungi, viruses, and parasites are needed, as well as ascertaining its mechanism of action and investigating its action in wound healing.

\section{DATA AVAILABILITY}

The datasets analyzed during the current study are available from the corresponding author on reasonable request.

\section{AUTHOR CONTRIBUTIONS}

AD-R carried out the design, conduct of the study, and wrote the manuscript. FB, MP, and PJ contributed to the idea, revised the manuscript and helped data interpretation and supervised the work. All authors read and approved the final manuscript.

\section{REFERENCES}

Altschul, S. F., Madden, T. L., Schaffer, A. A., Zhang, J., Zhang, Z., Miller, W., et al. (1997). Gapped BLAST and PSI-BLAST: a new generation of protein database search programs. Nucleic Acids Res. 25, 3389-3402. doi: 10.1093/nar/25.17.3389

Andersen, A. S., Sandvang, D., Schnorr, K. M., Kruse, T., Neve, S., Joergensen, B., et al. (2010). A novel approach to the antimicrobial activity of maggot debridement therapy. J. Antimicrob. Chemother. 65, 1646-1654. doi: 10.1093/ jac/dkq165

Anstead, C. A., Korhonen, P. K., Young, N. D., Hall, R. S., Jex, A. R., Murali, S. C., et al. (2015). Lucilia cuprina genome unlocks parasitic fly biology to underpin future interventions. Nat. Commun. 6:7344. doi: 10.1038/ncomms8344

Berova, N., Polavarapu, P. L., Nakanishi, K., and Woody, R. (2012). Comprehensive Chiroptical Spectroscopy: Applications in Stereochemical Analysis of Synthetic Compounds, Natural Products, and Biomolecules. Hoboken, NJ: John Wiley \& Sons, Inc. doi: 10.1002/9781118120392

Bexfield, A., Nigam, Y., Thomas, S., and Ratcliffe, N. A. (2004). Detection and partial characterisation of two antibacterial factors from the excretions/secretions of the medicinal maggot Lucilia sericata and their activity against methicillin-resistant Staphylococcus aureus (MRSA). Microbes Infect. 6, 1297-1304. doi: 10.1016/j.micinf.2004.08.011

Bochicchio, B., and Tamburro, A. M. (2002). Polyproline II structure in proteins: identification by chiroptical spectroscopies, stability, and functions. Chirality 14, 782-792. doi: 10.1002/chir.10153

Brown, K. L., and Hancock, R. E. (2006). Cationic host defense (antimicrobial) peptides. Curr. Opin. Immunol. 18, 24-30. doi: 10.1016/j.coi.2005.11.004

Bulet, P. (2008). Strategies for the discovery, isolation, and characterization of natural bioactive peptides from the immune system of invertebrates. Methods Mol. Biol. 494, 9-29. doi: 10.1007/978-1-59745-419-3_2

Bulet, P., Hetru, C., Dimarcq, J. L., and Hoffmann, D. (1999). Antimicrobial peptides in insects; structure and function. Dev. Comp. Immunol. 23, 329-344. doi: 10.1016/S0145-305X(99)00015-4

Bulet, P., and Stocklin, R. (2005). Insect antimicrobial peptides: structures, properties and gene regulation. Prot. Pept. Lett. 12, 3-11. doi: 10.2174/ 0929866053406011

Carretero, G. P. B., Saraiva, G. K. V., Cauz, A. C. G., Rodrigues, M. A., Kiyota, S., Riske, K. A., et al. (2018). Synthesis, biophysical and functional studies of two BP100 analogues modified by a hydrophobic chain and a cyclic peptide. Biochim. Biophys. Acta 1860, 1502-1516. doi: 10.1016/j.bbamem.2018. 05.003

Cazander, G., Van Veen, K. E., Bernards, A. T., and Jukema, G. N. (2009). Do maggots have an influence on bacterial growth? A study on the susceptibility of strains of six different bacterial species to maggots of Lucilia sericata and their excretions/secretions. J. Tissue Viab. 18, 80-87. doi: 10.1016/j.jtv.2009.02.005

\section{FUNDING}

This work was supported by the Colombian Science, Technology, and Innovation Department (Colciencias) through Colciencias-UAN agreement FP44842-384-2016 (Project code No. 125371250687). Funding was also received from the São Paulo Research Foundation (FAPESP) Grants 13/07467-1 to CeTICS-CEPID and from the Brazilian National Technological and Scientific Development Council (CNPq) Grant 472744/2012-7. AD-R received support through Colciencias grant (convocatoria 617, Colombia).

\section{ACKNOWLEDGMENTS}

We would like to thank Jason Garry for correcting the English, Abraham Espinoza-Culupú and Flávio Lopes Alves for their diligent help with part of the experimental work.

Cerovsky, V., and Bem, R. (2014). Lucifensins, the insect Defensins of biomedical importance: the story behind maggot therapy. Pharmaceuticals 7, 251-264. doi: 10.3390/ph7030251

Cerovsky, V., Zdarek, J., Fucik, V., Monincova, L., Voburka, Z., and Bem, R. (2010). Lucifensin, the long-sought antimicrobial factor of medicinal maggots of the blowfly Lucilia sericata. Cell Mol. Life Sci. 67, 455-466. doi: 10.1007/s00018009-0194-0

Cézard, C., Silva-Pires, V., Mullié, C., and Sonnet, P. (2011). Antibacterial Peptides: A Review Science against Microbial Pathogens: Communicating Current Research And Technological Advances, ed. A. Méndez-Vilas, Badajoz: Formatex Research Center.

Chaparro, E., and da Silva, P. I. J. (2016). Lacrain: the first antimicrobial peptide from the body extract of the Brazilian centipede Scolopendra viridicornis. Int. J. Antimicrob. Agents 48, 277-285. doi: 10.1016/j.ijantimicag.2016.05.015

Chay Pak Ting, B. P., Mine, Y., Juneja, L. R., Okubo, T., Gauthier, S. F., and Pouliot, Y. (2011). Comparative composition and antioxidant activity of Peptide fractions obtained by ultrafiltration of egg yolk protein enzymatic hydrolysates. Membranes 1, 149-161. doi: 10.3390/membranes1030149

Chernysh, S., Gordya, N., and Suborova, T. (2015). Insect antimicrobial peptide complexes prevent resistance development in bacteria. PLoS One 10:e0130788. doi: 10.1371/journal.pone.0130788

Chernysh, S., Gordya, N., Tulin, D., and Yakovlev, A. (2018). Biofilm infections between Scylla and Charybdis: interplay of host antimicrobial peptides and antibiotics. Infect Drug Resist. 11, 501-514. doi: 10.2147/IDR.S157847

Church, J. C. (1996). The traditional use of maggots in wound healing, and the development of larva therapy (biosurgery) in modern medicine. J. Altern. Complement. Med. 2, 525-527. doi: 10.1089/acm.1996.2.525

Cruz-Saavedra, L., Diaz-Roa, A., Gaona, M. A., Cruz, M. L., Ayala, M., CortesVecino, J. A., et al. (2016). The effect of Lucilia sericata- and Sarconesiopsis magellanica-derived larval therapy on Leishmania panamensis. Acta Trop. 164, 280-289. doi: 10.1016/j.actatropica.2016.09.020

Diamond, G., Beckloff, N., Weinberg, A., and Kisich, K. O. (2009). The roles of antimicrobial peptides in innate host defense. Curr. Pharm. Des. 15, 2377-2392. doi: 10.2174/138161209788682325

Diaz-Roa, A., Gaona, M. A., Segura, N. A., Suarez, D., Patarroyo, M. A., and Bello, F. J. (2014). Sarconesiopsis magellanica (Diptera: Calliphoridae) excretions and secretions have potent antibacterial activity. Acta Trop. 136, 37-43. doi: 10. 1016/j.actatropica.2014.04.018

El Shazely, B., Veverka, V., Fucik, V., Voburka, Z., Zdarek, J., and Cerovsky, V. (2013). Lucifensin II, a defensin of medicinal maggots of the blowfly Lucilia cuprina (Diptera: Calliphoridae). J. Med. Entomol. 50, 571-578. doi: 10.1603/ ME12208

Erdmann, G. R. (1987). Antibacterial action of Myiasis-causing flies. Parasitol. Today 3, 214-216. doi: 10.1016/0169-4758(87)90062-7 
Faisal, M., Saquib, Q., Alatar, A. A., Al-Khedhairy, A. A., Ahmed, M., Ansari, S. M., et al. (2016). Cobalt oxide nanoparticles aggravate DNA damage and cell death in eggplant via mitochondrial swelling and NO signaling pathway. Biol. Res. 49:20. doi: 10.1186/s40659-016-0080-9

Franta, Z., Vogel, H., Lehmann, R., Rupp, O., Goesmann, A., and Vilcinskas, A. (2016). Next generation sequencing identifies five major classes of potentially therapeutic enzymes secreted by Lucilia sericata medical maggots. Biomed. Res. Int. 2016:8285428. doi: 10.1155/2016/8285428

Giacometti, A., Cirioni, O., Barchiesi, F., Fortuna, M., and Scalise, G. (1999). Invitro activity of cationic peptides alone and in combination with clinically used antimicrobial agents against Pseudomonas aeruginosa. J. Antimicrob. Chemother. 44, 641-645. doi: 10.1093/jac/44.5.641

Giuliani, A., Pirri, G., and Nicoletto, S. F. (2006). Antimicrobial peptides: an overview of a promising class of therapeutics. Curr. Med. Chem. 2, 2449-2466.

Goff, M. L. (2001). A Fly for the Prosecution: How Insect Evidence Helps Solve Crimes. Cambridge, MA: Harvard University Press, 225.

Gordya, N., Yakovlev, A., Kruglikova, A., Tulin, D., Potolitsina, E., Suborova, T., et al. (2017). Natural antimicrobial peptide complexes in the fighting of antibiotic resistant biofilms: Calliphora vicina medicinal maggots. PLoS One 12:e0173559. doi: 10.1371/journal.pone.0173559

Gottrup, F., and Jorgensen, B. (2011). Maggot debridement: an alternative method for debridement. Eplasty 11:e33.

Gouy, M., Guindon, S., and Gascuel, O. (2010). SeaView Version 4: a multiplatform graphical user interface for sequence alignment and phylogenetic tree building. Mol. Biol. Evol. 27, 221-224. doi: 10.1093/molbev/msp259

Hardy, D. E. (1966). A Catalogue of the Diptera of the Americas south of the United States. Museu de Zoologia, Departamento de Zoologia, Universidade de Sapo Paulo. Sapo Paulo: Departamento de Zoologia, Secretaria da Agricultura do Estado de Sapo Paulo.

Hetru, C., and Bulet, P. (1997). Strategies for the isolation and characterization of antimicrobial peptides of invertebrates. Methods Mol. Biol. 78, 35-49. doi: 10.1385/0-89603-408-9:35

Higuchi, M., Masuyama, N., Fukui, Y., Suzuki, A., and Gotoh, Y. (2001). Akt mediates Rac/Cdc42-regulated cell motility in growth factor-stimulated cells and in invasive PTEN knockout cells. Curr. Biol. 11, 1958-1962. doi: 10.1016/ S0960-9822(01)00599-1

Hoffmann, J. A., and Hetru, C. (1992). Insect defensins: inducible antibacterial peptides. Immunol. Today 13, 411-415. doi: 10.1016/0167-5699(92)90092-L

Hou, F., Li, J., Pan, P., Xu, J., Liu, L., Liu, W., et al. (2011). Isolation and characterisation of a new antimicrobial peptide from the skin of Xenopus laevis. Int. J. Antimicrob. Agents 38, 510-515. doi: 10.1016/j.ijantimicag.2011.07.012

Huberman, L., Gollop, N., Mumcuoglu, K. Y., Breuer, E., Bhusare, S. R., Shai, Y., et al. (2007). Antibacterial substances of low molecular weight isolated from the blowfly. Lucilia sericata. Med. Vet. Entomol. 21, 127-131. doi: 10.1111/j.13652915.2007.00668.x

Hyde, A. J., Parisot, J., Mcnichol, A., and Bonev, B. B. (2006). Nisin-induced changes in Bacillus morphology suggest a paradigm of antibiotic action. Proc. Natl. Acad. Sci. U.S.A. 103, 19896-19901. doi: 10.1073/pnas.06083 73104

Jiang, K.-C., Sun, X.-J., Wang, W., Liu, L., Cai, Y., Chen, Y.-C., et al. (2012). Excretions/Secretions from bacteria-pretreated maggot are more effective against Pseudomonas aeruginosa Biofilms. PLoS One 7:e49815. doi: 10.1371/ journal.pone.0049815

Johnson, D. I. (1999). Cdc42: an essential Rho-type GTPase controlling eukaryotic cell polarity. Microbiol. Mol. Biol. Rev. 63, 54-105. doi: 10.1385/0-89603$4\{\backslash$ break $\} 08-9: 35$

Kawabata, T., Mitsui, H., Yokota, K., Ishino, K., Oguma, K., and Sano, S. (2010). Induction of antibacterial activity in larvae of the blowfly Lucilia sericata by an infected environment. Med. Vet. Entomol. 24, 375-381. doi: 10.1111/j.13652915.2010.00902.x

Khamis, A. M., Essack, M., Gao, X., and Bajic, V. B. (2015). Distinct profiling of antimicrobial peptide families. Bioinformatics 31, 849-856. doi: 10.1093/ bioinformatics/btu738

Landry, B. S., Dextraze, L., and Boivin, G. (1993). Random amplified polymorphic DNA markers for DNA fingerprinting and genetic variability assessment of minute parasitic wasp species (Hymenoptera: Mymaridae and Trichogrammatidae) used in biological control programs of phytophagous insects. Genome 36, 580-587. doi: 10.1139/g93-078
Lee, K., Boyd, K. L., Parekh, D. V., Kehl-Fie, T. E., Baldwin, H. S., Brakebusch, C., et al. (2013). Cdc42 promotes host defenses against fatal infection. Infect. Immun. 81, 2714-2723. doi: 10.1128/IAI.01114-12

Lorenzini, D. M., Da Silva, P. I. Jr., Fogaca, A. C., Bulet, P., and Daffre, S. (2003). Acanthoscurrin: a novel glycine-rich antimicrobial peptide constitutively expressed in the hemocytes of the spider Acanthoscurria gomesiana. Dev. Comp. Immunol. 27, 781-791. doi: 10.1016/S0145-305X(03)00058-2

Magi, G., Marini, E., and Facinelli, B. (2015). Antimicrobial activity of essential oils and carvacrol, and synergy of carvacrol and erythromycin, against clinical, erythromycin-resistant Group A Streptococci. Front. Microbiol. 6:165. doi: 10. 3389/fmicb.2015.00165

Mariluis, J., and Mulieri, P. (2003). The distribution of the Calliphoridae in Argentina (Diptera). Revista de la Sociedad Entomológica Argentina 62, 85-97.

Mariluis, J. C., and Peris, S. V. (1984). Datos para una sinopsis de los Calliphoridae neotropicales. EOS Revista Espa ola de Entomología 40, 67-86.

Mumcuoglu, K. Y. (2001). Clinical applications for maggots in wound care. Am. J. Clin. Dermatol. 2, 219-227. doi: 10.2165/00128071-200102040-00003

Nagao, T., Mishima, D., Javkhlantugs, N., Wang, J., Ishioka, D., Yokota, K., et al. (2015). Structure and orientation of antibiotic peptide alamethicin in phospholipid bilayers as revealed by chemical shift oscillation analysis of solid state nuclear magnetic resonance and molecular dynamics simulation. Biochim. Biophys. Acta 1848, 2789-2798. doi: 10.1016/j.bbamem.2015.07.019

Nan, Y. H., Bang, J.-K., Jacob, B., Park, I.-S., and Shin, S. Y. (2012). Prokaryotic selectivity and LPS-neutralizing activity of short antimicrobial peptides designed from the human antimicrobial peptide LL-37. Peptides 35, 239-247. doi: 10.1016/j.peptides.2012.04.004

Nigam, Y., Dudley, E., Bexfield, A., Bond, A. E., Evans, J., and James, J. (2010). "The physiology of wound healing by the medicinal maggot, Lucilia sericata", in Advances in Insect Physiology, Vol. 39, ed. S. J. Simpson (London: Academic Press Ltd-Elsevier Science Ltd.), 39-81.

Nocker, A., Caspers, M., Esveld-Amanatidou, A., Van Der Vossen, J., Schuren, F., Montijn, R., et al. (2011). Multiparameter viability assay for stress profiling applied to the food pathogen Listeria monocytogenes F2365. Appl. Environ. Microbiol. 77, 6433-6440. doi: 10.1128/AEM.00142-11

O’Meara, S., Al-Kurdi, D., Ologun, Y., Ovington, L. G., Martyn-St James, M., and Richardson, R. (2014). Antibiotics and antiseptics for venous leg ulcers. Cochrane Database Syst. Rev. 14:Cd003557. doi: 10.1002/14651858.CD003557. pub5

Oren, Z., and Shai, Y. (1998). Mode of action of linear amphipathic $\alpha$-helical antimicrobial peptides. Pept. Sci. 47, 451-463. doi: 10.1002/(SICI)10970282(1998)47:6<451::AID-BIP4>3.0.CO;2-F

Pape, T., Wolff, M., and Amat, E. (2004). Los califóridos, éstridos, rinofóridos y sarcofágidos (Diptera: Calliphoridae, Oestridae, Rhinophoridae y Sarcophagidae) de Colombia. Biota Colombiana 5, 201-208.

Phoenix, D. A., Dennison, S. R., and Harris, F. (2013). Anionic antimicrobial peptides. Antimicrob. Pept. 10, 585-606. doi: 10.1002/9783527652853. ch9783527652853

Polakovicova, S., Polak, S., Kuniakova, M., Cambal, M., Caplovicova, M., Kozanek, M., et al. (2015). The effect of salivary gland extract of Lucilia sericata maggots on human dermal fibroblast proliferation within collagen/hyaluronan membrane in vitro: transmission electron microscopy study. Adv. Skin Wound Care 28, 221-226. doi: 10.1097/01.ASW.0000461260.03630.a0

Poppel, A. K., Vogel, H., Wiesner, J., and Vilcinskas, A. (2015). Antimicrobial peptides expressed in medicinal maggots of the blow fly Lucilia sericata show combinatorial activity against bacteria. Antimicrob. Agents Chemother. 59, 2508-2514. doi: 10.1128/AAC.05180-14

Raposio, E., Bortolini, S., Maistrello, L., and Grasso, D. A. (2017). Larval therapy for chronic cutaneous ulcers: historical review and future perspectives. Wounds 29, 367-373.

Ratcliffe, N., Azambuja, P., and Mello, C. B. (2014). Recent advances in developing insect natural products as potential modern day medicines. Evid. Based Complement. Alternat. Med. 2014:904958. doi: 10.1155/2014/904958

Riciluca, K. C., Sayegh, R. S., Melo, R. L., and Silva, P. I. Jr. (2012). Rondonin an antifungal peptide from spider (Acanthoscurria rondoniae) haemolymph. Results Immunol. 2, 66-71. doi: 10.1016/j.rinim.2012.03.001

Robinson, W. (1935). Stimulation of healing in non-healing wounds by allantoin in maggot secretions and of wide biological distribution. J. Bone Joint Surg. Am. $17,267-271$. 
Rueda, L. C., Ortega, L. G., Segura, N. A., Acero, V. M., and Bello, F. (2010). Lucilia sericata strain from Colombia: experimental colonization, life tables and evaluation of two artificial diets of the blowfly Lucilia sericata (Meigen) (Diptera: Calliphoridae), Bogota, Colombia strain. Biol. Res. 43, 197-203. doi: 10.4067/S0716-97602010000200008

Sandeman, R. M., Feehan, J. P., Chandler, R. A., and Bowles, V. M. (1990). Tryptic and chymotryptic proteases released by larvae of the blowfly, Lucilia cuprina. Int. J. Parasitol. 20, 1019-1023. doi: 10.1016/0020-7519(90)90044-N

Sayegh, R. S., Batista, I. F., Melo, R. L., Riske, K. A., Daffre, S., Montich, G., et al. (2016). Longipin: an Amyloid Antimicrobial Peptide from the Harvestman Acutisoma longipes (Arachnida: Opiliones) with preferential affinity for anionic vesicles. PLoS One 11:e0167953. doi: 10.1371/journal.pone.0167953

Shaw, K. L., Grimsley, G. R., Yakovlev, G. I., Makarov, A. A., and Pace, C. N. (2001). The effect of net charge on the solubility, activity, and stability of ribonuclease Sa. Protein Sci. 10, 1206-1215. doi: 10.1110/ps.440101

Sherman, R. A., Hall, M. J., and Thomas, S. (2000). Medicinal maggots: an ancient remedy for some contemporary afflictions. Annu. Rev. Entomol. 45, 55-81. doi: 10.1146/annurev.ento.45.1.55

Shi, W., Li, C., Li, M., Zong, X., Han, D., and Chen, Y. (2016). Antimicrobial peptide melittin against Xanthomonas oryzae pv. oryzae, the bacterial leaf blight pathogen in rice. Appl. Microbiol. Biotechnol. 100, 5059-5067. doi: 10.1007/ s00253-016-7400-4

Silva, P. I. Jr., Daffre, S., and Bulet, P. (2000). Isolation and characterization of gomesin, an 18-residue cysteine-rich defense peptide from the spider Acanthoscurria gomesiana hemocytes with sequence similarities to horseshoe crab antimicrobial peptides of the tachyplesin family. J. Biol. Chem. 275, 33464-33470. doi: 10.1074/jbc.M001491200

Spilsbury, K., Cullum, N., Dumville, J., O'meara, S., Petherick, E., and Thompson, C. (2008). Exploring patient perceptions of larval therapy as a potential treatment for venous leg ulceration. Health Expect. 11, 148-159. doi: 10.1111/j.1369-7625.2008.00491.x

Sze, S. H., Dunham, J. P., Carey, B., Chang, P. L., Li, F., Edman, R. M., et al. (2012). A de novo transcriptome assembly of Lucilia sericata (Diptera: Calliphoridae) with predicted alternative splices, single nucleotide polymorphisms and transcript expression estimates. Insect Mol. Biol. 21, 205-221. doi: 10.1111/j. 1365-2583.2011.01127.x

Telford, G., Brown, A. P., Kind, A., English, J. S., and Pritchard, D. I. (2011). Maggot chymotrypsin I from Lucilia sericata is resistant to endogenous wound protease inhibitors. Br. J. Dermatol. 164, 192-196. doi: 10.1111/j.1365-2133.2010.10081.x

Teng, D., Wang, X., Xi, D., Mao, R., Zhang, Y., Guan, Q., et al. (2014). A dual mechanism involved in membrane and nucleic acid disruption of AvBD103b, a new avian defensin from the king penguin, against Salmonella enteritidis CVCC3377. Appl. Microbiol. Biotechnol. 98, 8313-8325. doi: 10.1007/s00253014-5898-x

Thomas, A. M., Harding, K. G., and Moore, K. (1999). The structure and composition of chronic wound eschar. J. Wound Care 8, 285-287. doi: 10.12968/jowc.1999.8.6.25881

Thomas, S., Andrews, A. M., Hay, N. P., and Bourgoise, S. (1999). The antimicrobial activity of maggot secretions: results of a preliminary study. J. Tissue Viab. 9, 127-132. doi: 10.1016/S0965-206X(99)80032-1

Titulaer, M. K. (2013). Candidate biomarker discovery for angiogenesis by automatic integration of Orbitrap MS1 spectral- and X!Tandem MS2 sequencing information. Genomics Proteomics Bioinformatics 11, 182-194. doi: 10.1016/j.gpb.2013.02.002

Valachova, I., Bohova, J., Palosova, Z., Takac, P., Kozanek, M., and Majtan, J. (2013). Expression of lucifensin in Lucilia sericata medicinal maggots in infected environments. Cell Tissue Res. 353, 165-171. doi: 10.1007/s00441-013-1626-6

Van Aelst, L., and Symons, M. (2002). Role of Rho family GTPases in epithelial morphogenesis. Genes Dev. 16, 1032-1054. doi: 10.1101/gad.978802

van der Plas, M. J., Jukema, G. N., Wai, S. W., Dogterom-Ballering, H. C., Lagendijk, E. L., Van Gulpen, C., et al. (2008). Maggot excretions/secretions are differentially effective against biofilms of Staphylococcus aureus and Pseudomonas aeruginosa. J. Antimicrob. Chemother. 61, 117-122. doi: 10.1093/ $\mathrm{jac} / \mathrm{dkm} 407$

Velema, W. A., Van Der Berg, J. P., Hansen, M. J., Szymanski, W., Driessen, A. J. M., and Feringa, B. L. (2013). Optical control of antibacterial activity. Nat. Chem. 5, 924-928. doi: 10.1038/nchem.1750

Wennerberg, K., and Der, C. J. (2004). Rho-family GTPases: it's not only Rac and Rho (and I like it). J. Cell Sci. 117, 1301-1312. doi: 10.1242/jcs.01118

Wiegand, I., Hilpert, K., and Hancock, R. E. (2008). Agar and broth dilution methods to determine the minimal inhibitory concentration (MIC) of antimicrobial substances. Nat. Protoc. 3, 163-175. doi: 10.1038/nprot.2007.521

Wolff, H., and Hansson, C. (2005). Rearing larvae of Lucilia sericata for chronic ulcer treatment-an improved method. Acta Derm. Venereol. 85, 126-131. doi: 10.1080/00015550510025533

Yakovlev, A. Y., Nesin, A. P., Simonenko, N. P., Gordya, N. A., Tulin, D. V., Kruglikova, A. A., et al. (2017). Fat body and hemocyte contribution to the antimicrobial peptide synthesis in Calliphora vicina R.-D. (Diptera: Calliphoridae) larvae. In Vitro Cell Dev. Biol. Anim. 53, 33-42. doi: 10.1007/ s11626-016-0078-1

Yang, N., Liu, X., Teng, D., Li, Z., Wang, X., Mao, R., et al. (2017). Antibacterial and detoxifying activity of NZ17074 analogues with multi-layers of selective antimicrobial actions against Escherichia coli and Salmonella enteritidis. Sci. Rep. 7:3392. doi: 10.1038/s41598-017-03664-2

Yeaman, M. R., and Yount, N. Y. (2003). Mechanisms of antimicrobial peptide action and resistance. Pharmacol. Rev. 55, 27-55. doi: 10.1124/pr.55.1.2

Yi, H. Y., Chowdhury, M., Huang, Y. D., and Yu, X. Q. (2014). Insect antimicrobial peptides and their applications. Appl. Microbiol. Biotechnol. 98, 5807-5822. doi: 10.1007/s00253-014-5792-6

Zhang, Z., Wang, J., Zhang, B., Liu, H., Song, W., He, J., et al. (2013). Activity of antibacterial protein from maggots against Staphylococcus aureus in vitro and in vivo. Int. J. Mol. Med. 31, 1159-1165. doi: 10.3892/ijmm.2013.1291

Conflict of Interest Statement: The authors declare that the research was conducted in the absence of any commercial or financial relationships that could be construed as a potential conflict of interest.

Copyright (c) 2018 Díaz-Roa, Patarroyo, Bello and Da Silva. This is an open-access article distributed under the terms of the Creative Commons Attribution License (CC BY). The use, distribution or reproduction in other forums is permitted, provided the original author(s) and the copyright owner(s) are credited and that the original publication in this journal is cited, in accordance with accepted academic practice. No use, distribution or reproduction is permitted which does not comply with these terms. 